\title{
Composite Molding of SPECTRA $\otimes$ Extended Chain Polyethylene Fibers in a Flexible Rubber Matrix
}

Federal Manufacturing \& Technologies

Kevin McKeehan

KCP-613-5988

Published August 1997

RECEIVED

Allf 191997

OSTI

Final Report/Project Accomplishments Summary CRADA Number 95-KCP-1022

Approved for public release; distribution is unlimited.

MASTER

HH DISTRIBUTION OF THIS DOCUMENT IS UNLIMTED.

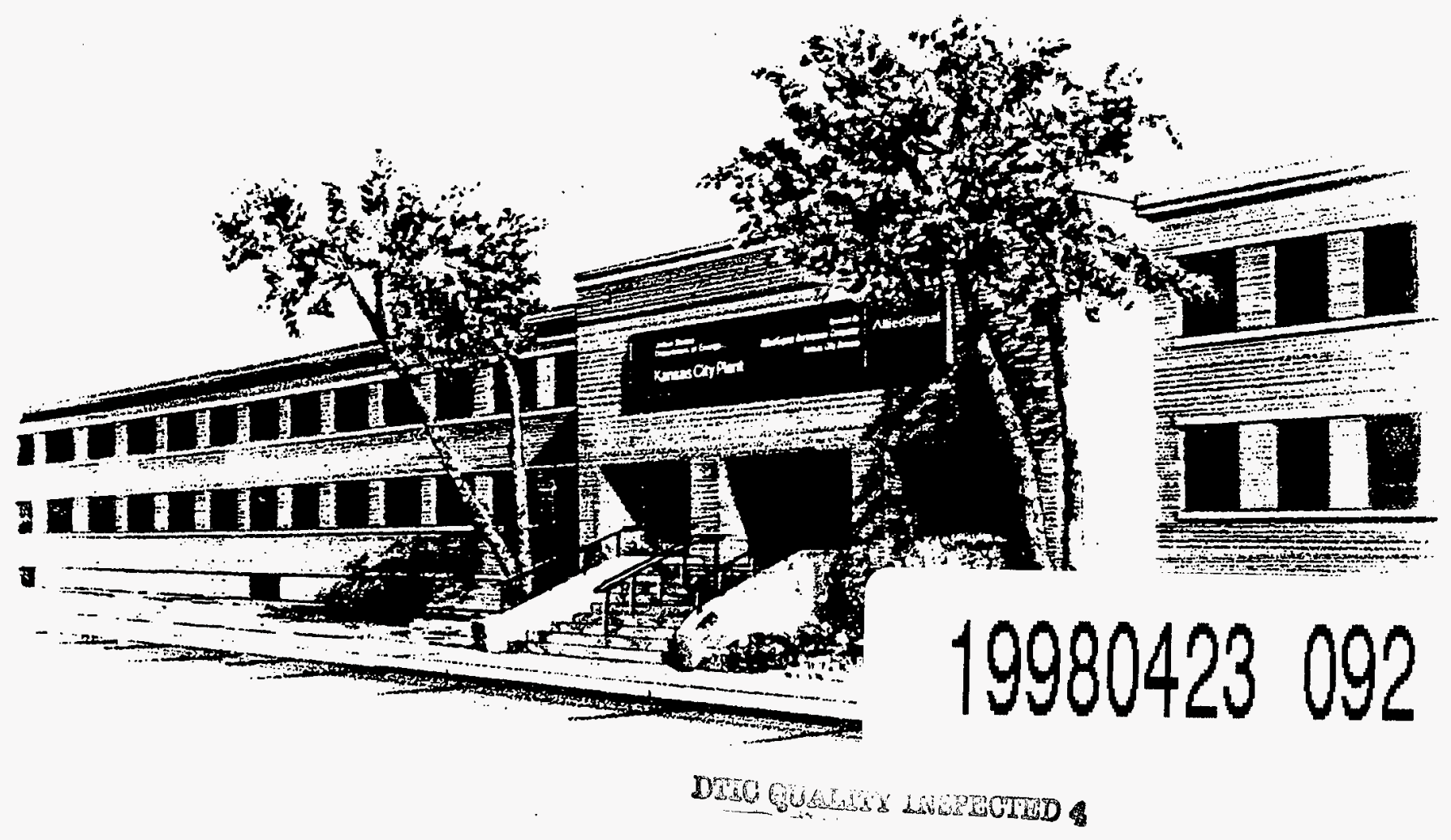

Prepared Under Contract Number DE-AC04-76-DP00613 for the United States Department of Energy 


\section{DISCLAIMER}

This report was prepared as an account of work sponsored by an agency of the United States Government. Neither the United States Government nor any agency thereof, nor any of their employees, makes any warranty, express or implied, or assumes any legal liability or responsibility for the accuracy, completeness, or usefulness of any information, apparatus, product, or process disclosed, or represents that its use would not infringe privately owned rights. Reference herein to any specific commercial product, process, or service by trade names, trademark, manufacturer, or otherwise, does not necessarily constitute or imply its endorsement, recommendation, or favoring by the United States Government or any agency thereof. The views and opinions of authors expressed herein do not necessarily state or reflect those of the United States Government or any agency thereof.

Printed in the United States of America.

This report has been reproduced from the best available copy.

Available to DOE and DOE contractors from the Office of Scientific and Technical Information, P. O. Box 62, Oak Ridge, Tennessee 37831; prices available from (615) 576-8401, FTS 626-8401.

Available to the public from the National Technical Information Service, U. S. Department of Commerce, 5285 Port Royal Rd., Springfield, Virginia 22161.

AlliedSignal Inc.

Federal Manufacturing Department of Energy under Contract Number 
KCP-613-5988

Distribution Category UC-706

Approved for public release; distribution is unlimited.

COMPOSITE MOLDING OF SPECTRA® EXTENDED CHAIN POLYETHYLENE FIBERS IN A FLEXIBLE RUBBER MATRIX

Kevin McKeehan

Published August 1997

Final Report/Project Accomplishments Summary

CRADA Number 95-KCP-1022 


\section{Composite Molding of SPECTRA ${ }^{\circledR}$ Extended Chain Polyethylene Fibers in a Flexible Rubber Matrix Project Accomplishments Summary CRADA Number 95-KCP-1022}

Date: July 28,1997

Revision: 0

\section{A. Parties}

The project is a relationship between

AlliedSignal FM\&T

THETA Technologies, Inc.

2000 E $95^{\text {th }}$ Street

479 Charlotta Ave SE

PO Box 419159

Kansas City, MO 64141-6159

Palm Bay, FL 32909

\section{B. Background}

THETA Technologies, Inc. is a multidisciplinary research and development firm involved in the design and development of affordable, lightweight, high ballistic protection modular body armor ensemble for future military, law enforcement, and specialized commercial market applications.

In the course of their research, THETA Technologies, Inc. identified that current state-of-the-art in ballistic protection and overall composite reinforcement is a high density extended chain polyethylene (HDECPE) fiber known as SPECTRA ${ }^{\circledR}$, a product of AlliedSignal Fibers, Petersburg, VA. SPECTRA ${ }^{\circledR}$ is ten times stronger than steel of equal weight. As a non-aramid polyethylene, it offers highly desirable properties in areas of resistance to chemical degradation, virtual neutral buoyancy (0.97), and increased capacity for composite bonding over competing nylon-based fibers, such as KEVLAR ${ }^{\circledR}$. SPECTRA Shield ${ }^{\mathrm{TM}}$, a woven ballistic-resistant fabric using the SPECTRA ${ }^{\circledR}$ fiber, is presently the most effective ballistic-resistant component for both flexible and hard plate composite armors.

THETA Technologies, Inc. identified a market need for a boot sole design that would measurably increase protection to the wearer without significantly degrading performance in other areas, such as flexibility and overall weight. THETA Technologies, Inc. proposed a nitrile rubber and SPECTRA ${ }^{\circledR}$ fiber matrix to produce an optimal boot sole.

This CRADA applied AlliedSignal Federal Manufacturing \& Technology's (FM\&T) expertise and facilities together with THETA Technologies, Inc. knowledge of military and civilian systems integration and engineering to create a practical process for combining the SPECTRA ${ }^{\circledR}$ within a semiflexible composite matrix. FM\&T combined the knowledge of advanced composite molding and plasma cleaning processes with the ability to fabricate suitable compression molds and 
prepared a selection of test block samples of various percentages by weight/thicknesses of both SPECTRA ${ }^{\circledR}$ chopped fiber and woven/coated SPECTRA Shield ${ }^{\mathrm{TM}}$ fabric.

THETA Technologies, Inc. expected to apply the developed technology through either direct manufacturing or through licensing agreement, or both, to a wide variety of existing and evolving markets. The potential for this technology is indeed high, and could result in the emergence of THETA Technologies, Inc. as a primary provider or licenser of a highly specialized line of ballistic- and abrasion-resistant semiflexible industrial components, protective footwear, and military items and equipment. The project assisted FM\&T in obtaining experience in cutting, plasma cleaning, and molding different configurations of SPECTRA ${ }^{\circledR}$ and provided evaluation of SPECTRA ${ }^{\mathbb{B}}$ in the area of molding a reinforcing "fabric" within a silicone material matrix. The project also assisted FM\&T in maintaining competency in development of a patentable process involving composite resins, fabrication of molds and sample test blocks, design creativity, cost containment, design for manufacturability, and performance of select Military Specification testing.

\section{Description}

The objective of this CRADA effort was to develop and test a process for combining the SPECTRA ${ }^{\circledR}$ fiber, in both chopped fiber and SPECTRA Shield ${ }^{\text {TM }}$ form, within a semiflexible nitrile composite having desirable and marketable properties in areas of resistance to penetration and mechanical stress.

THETA Technologies, Inc. acquired the appropriate Military Specification performance data to determine the parameters for the experimental test blocks. Also THETA Technologies, Inc. procured and provided to FM\&T the materials required for the fabrication of the test blocks. In addition, THETA Technologies, Inc. subcontracted a qualified laboratory to perform V50 ballistic testing on sample test blocks of various configurations. Furthermore, THETA Technologies, Inc. assisted with data collation and preparation of the final report.

FM\&T worked with THETA Technologies, Inc. to develop an experimental test block matrix to outline the various configurations to be fabricated. FM\&T also aided THETA Technologies, Inc. in the development of suitable ASTM-based testing procedures and performed those tests. In addition, FM\&T assisted in data collation and preparation of the final report.

Table \#1 outlines the tasks and the lead organization for the CRADA activities as established in the Joint Work Statement dated June 1995. 
Table \#1 - Joint Work Statement Task Outline

\begin{tabular}{|l|l|}
\hline Task & Description \\
\hline 1 & $\begin{array}{l}\text { Determine Required/Desired Standards of Performance of Existing } \\
\text { Penetration-Resistant Boot Soles. (TTI) }\end{array}$ \\
\hline 2 & $\begin{array}{l}\text { Identify preferred Mil Spec performance test procedures for boot } \\
\text { soles. (TTI) }\end{array}$ \\
\hline 3 & $\begin{array}{l}\text { Identify the materials and manufacturing process for the existing } \\
\text { high-performance boot soles. (TTI) }\end{array}$ \\
\hline 4 & $\begin{array}{l}\text { Determine physical and material configuration(s) of the prototype } \\
\text { boot soles. (TTI) }\end{array}$ \\
\hline 5 & Review/Approval of Molding Operation. (FM\&T) \\
\hline 6 & Compression Mold Fabrication. (FM\&T) \\
\hline 7 & Prototype Molding. (FM\&T) \\
\hline 8 & Test \& Evaluation of Test Blocks. (FM\&T) \\
\hline 9 & Data Collation and Analysis. (TTI) \\
\hline 10 & Reporting. (TTI) \\
\hline
\end{tabular}

THETA Technologies, Inc. conducted a search for existing boot manufacturers to solicit legal permission to obtain and replicate processes and ingredients used in the fabrication of boot soles. The search concluded that the manufacturing processes are outlined in the Military Specification. FM\&T utilized this information and made minor adjustments to the manufacturing parameters to optimize test block fabrication. Therefore, the experimental test blocks were fabricated with only controlled variations in procedures in order to isolate and measure the effects of the SPECTRA ${ }^{\circledR}$.

The project testing clearly revealed that the SPECTRA ${ }^{\circledR}$ HDECPE fiber can be successfully molded into a semiflexible rubber matrix without apparent degradation of the material's basic ballistic properties. Of the three SPECTRA ${ }^{\circledR}$ products used, the woven SPECTRA ${ }^{\oplus}$ material imparted the greatest degree of ballistic protection to the composite structure. This material also presented very favorable mechanical properties in that it resisted delamination in flex testing. Mechanical performance of the SPECTRA Shield ${ }^{\mathrm{TM}}$ suffered because it relies on a thin laminate to adhere multiple sheets of the material together, and the laminate was prone to failure under mechanical testing. Inclusion of chopped SPECTRA ${ }^{\circledR}$ fiber in the composite was observed to actually degrade overall ballistic performance of the test block below the relative resistance of the native nitrile component. However, inclusion of chopped SPECTRA ${ }^{\circledR}$ fiber did appear to reduce or eliminate post-mold shrinkage of the composite material, a property which may have application in other processes. 


\section{Expected Economic Impact}

THETA Technologies, Inc. has benefited greatly from the successful accomplishment of this CRADA and intends to apply the results toward the development of several unique ballistic-resistant products. One area being pursued with Natick Laboratories RDT\&E division is a unique line of lightweight penetration- and explosion-resistant boot soles for special-purpose applications such as military and civilian law enforcement Emergency Ordnance Disposal (EOD). In another initiative, THETA Technologies, Inc. has teamed with a commercial producer of ballistic plate inserts for protective vests. In response to a DoD Small Business Innovation Research solicitation, a formal proposal to produce a titanium ballistic plate insert with a front-face anti-spall layer consisting of coated SPECTRA ${ }^{\circledR}$ material and nitrile has been submitted to the DoD. The anti-spall layer will reduce secondary injury to the wearer caused by fragmentation of the jacketing of large-caliber bullets when they strike the ballistic plate insert.

The technology produced by this CRADA has the potential for significant impact on the ballistic protective garment and accoutrement industries on an international level. Presently, there is an ongoing international initiative to ban mine warfare. Along with that initiative is an implicit requirement to neutralize existing land mine areas, with a clear need for increased protection to personnel involved in those activities. As a result of the CRADA, THETA Technologies, Inc. is in a position to produce and market a specialized line of protective overboots to the US military, international agencies, and appropriate foreign organizations. In the area of ballistic plates, the CRADA process and resulting anti-spall layer for lightweight, high-performance titanium ballistic inserts could revolutionize the industry state-of-the-art by creating an extremely lightweight National Institute of Justice Level IV protective system, a system that does not yet exist.

A conservative estimate centered around a small, specialized manufacturing facility, is that 10 to 15 jobs will be created with gross annual revenues approximating $\$ 500,000$ to $\$ 750,000$. Indirect benefits to the consumer/taxpayer will occur through fewer and less serious injuries encountered by military and civilian law enforcement personnel, with a concomitant reduction in medical, rehabilitation, and retirement costs to local and government agencies.

\section{E. Benefits to DOE}

This CRADA provided FM\&T the opportunity to work with SPECTRA ${ }^{\circledR}$ fibers and SPECTRA Shield ${ }^{\mathrm{TM}}$ that it would not otherwise have the impetus to work on. The project assisted FM\&T in obtaining experience in cutting, plasma cleaning, and molding different configurations of SPECTRA ${ }^{\circledR}$ and providing evaluation of SPECTRA ${ }^{\mathbb{B}}$ in the area of molding a reinforcing "fabric" within a silicone material matrix. FM\&T had no previous working knowledge in the area of molding a fabric in a rubber matrix. Therefore, FM\&T gained insights into fabric location/lay-up in the rubber matrix. 
This experience will benefit FM\&T in future production of pressure pads and other WR production by reducing scrap due to material exposure on the edges of the product. The project will also assist FM\&T in maintaining competency in development of a patentable process involving composite resins, fabrication of molds and sample test blocks, design creativity, cost containment, design for manufacturability, and performance of select Military Specification testing.

\section{F. Industry Area}

Industries benefiting from this project include the military and the law enforcement industry.

\section{G. Project Status}

This project was completed in May 1997 with the delivery of the test blocks to THETA Technologies, Inc.

\section{H. Point of Contact for Project Information}

Ken Bauer

US Department of Energy

Kansas City Area Office

PO Box 410202

Kansas City, MO 64141-0202

Telephone: (816) 997-3917

Fax: (816) $997-5059$
Kevin McKeehan

AlliedSignal FM\&T

PO Box 419159

Kansas City, MO 64141-6159

Telephone: (816) 997-4583

Fax: (816) 997-7068

\section{Company Size and Point of Contact}

THETA Technologies, Inc. is a single-employee small research and development firm incorporated under the laws of the State of Florida.

Kenneth Bell - President \& CEO

Phone: (407) 306-5043

\section{J. Project Examples}

AlliedSignal has no tangible items to be used in a demonstration.

\section{K. Technology Commercialization}

Is it expected that a product or process will be commercialized.

Commercialization Plan not yet available. 
$L$ Release of Information

I have reviewed the attached Project Accomplishment Summary prepared by

Allied Signal FM \&T and agree that the information about our CRADA may be released for external distribution.

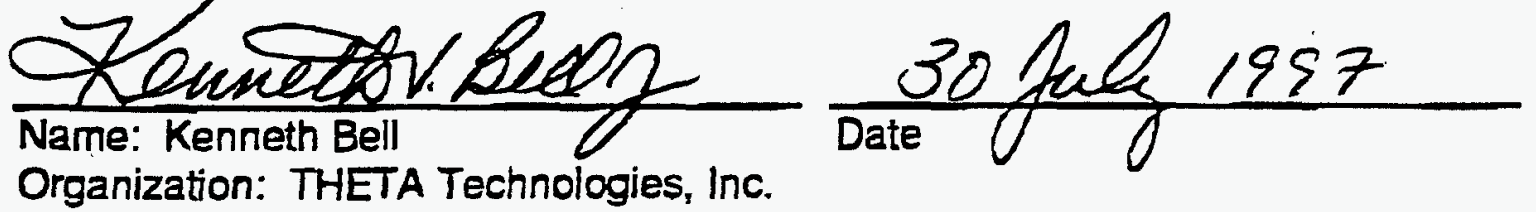

Title: President \& CEO

6 


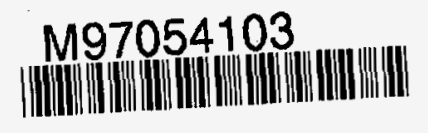

Report Number (14) KCP - $6 / 3-5988$

Publ. Date (11) 199708

Sponsor Code (18) DOE/DP

UC Category (19) UC-706, DDE/ER 